\title{
Informal governance and legitimacy in EU politics
}

\author{
Dr Mareike Kleine \\ Associate Professor of EU and international politics \\ London School of Economics and Political Science \\ European Institute \\ Houghton Street \\ London WC2A 2AE \\ United Kingdom \\ m.o.kleine@lse.ac.uk
}

Keywords: informal governance, legitimacy, EU politics, transparency

\begin{abstract}
:
Informal governance often holds an aura of the covert and exclusive-aspects that are difficult to square with the ideal of a democratic process. Unfortunately, existing analyses mostly focus on the effect of informal governance on transparency, ignoring other channels through which a political order may generate legitimacy. However, existing analyses quite often conflate different types of informal governance or consider predominantly its effect on transparency and accountability. This paper argued that the relationship between informal governance and legitimacy is much more complex and to some extent even counter-intuitive. To see this, I distinguish three channels of legitimation - input, throughput, and output — and discuss how various forms of informal governance affect it. The paper has implications for scholarly debates on the legitimacy of global governance, studies of informal governance, and practical implications for the reform of international organizations.
\end{abstract}

Acknowledgement: I thank Doreen Allerkamp and Nikoleta Yordanova for their comments on a first rough draft of this article. 


\section{Introduction}

Can informal governance ever be legitimate? An intuitive answer to this question is probably no. The term informality reminds one of smoke-filled backrooms, mobsters, and illicit business. It holds an aura of the covert, exclusive, if not illegal, all of which is difficult to square with the ideal of a democratic process that is inclusive, deliberative, and transparent. Informality, it seems, is the symptom of a pathological political order whose legitimacy is eroding.

Before we jump to conclusions about the relationship of informality and legitimacy, we should recognize that scholarship on formal and informal politics does not represent a unified school of thought. The term "informality" has been used to describe very different observations ranging from illegal behavior to the emergence of uncodified norms and rules. Unsurprisingly, explanations of these diverse phenomena differ widely (Kleine 2014, 115). At the root of this confusion is the fact that different disciplines and schools already disagree about what constitutes "formality." While especially comparative scholars equate formality with public structures and, therefore, locate informality in the private realm, other disciplines approach informality more broadly as the opposite of written rules.

Because of the broad use of the term "informality, the goal of this paper is twofold. First, it seeks to bring some order into the debate about the different meanings of informality and the normative debates associated with them. It argues that one type of informal governance in particular, understood as systematic departures from written rules and procedures (Kleine 2014, 304), raises interesting questions about the legitimacy of political orders. Second, the paper asks how this specific type of informal governance as systematic departures from formal rules affects the capacity of a political order to generate the legitimacy that is necessary to sustain it. Examples from the European Union (EU) will be used to illustrate the exercise. The central argument is that-contrary to conventional wisdom-informal governance may under certain conditions even strengthen the legitimacy of a political order. Distinguishing three dimensions of legitimacy-input, throughput and output-I find that informal governance has the capacity to stabilize the political order and enhance the involvement in a decision of those that are most affected by it.

Although there is a vast and sophisticated debate on the legitimacy of global governance, there is surprisingly little direct engagement with its informal aspects. If informality plays a role in this debate, it is typically, from a procedural point of view, associated with a lack of transparency and assumed to have a depreciative effect on the legitimacy of the political order in question. This paper contributes to these debates, firstly, by considering a specific concept of informal governance that has become prominent in the International Relations literature and, secondly, by evaluating the effect of informal governance along more than just a procedural dimension of legitimacy. Apart from these contributions to the scholarly literature, the discussion has important practical implications. If we want to improve the democratic quality of an international political order by making it more open and transparent, we need to be aware of the relationship between informal governance and legitimacy, for we might merely be fighting symptoms and, even worse, contribute to the erosion of legitimacy along a different dimension. 


\section{Informal governance and legitimacy in the literature}

Before assessing the effects of informal governance, it is necessary to define this concept in more detail. Most generally, informality can be described as the observation that the practices we observe do not appear to follow from formal rules. Therefore, a precondition for any definition of informal governance is to identify what makes a rule formal and effective.

\section{Definitions of informal governance in comparative politics}

Given their focus on the comparative study of government, students of comparative politics typically associate formality with the existence of enforceable state structures. Informal practices are consequently thought to emerge independently of or in contradiction to existing state structures. In their seminal article on the topic, for example, Helmke and Levitsky (2004, 727, italics added) define informal institutions "as socially shared rules, usually unwritten, that are created, communicated, and enforced outside of officially sanctioned channels."

Helmke and Levitsky differentiate further between four behavioral outcomes. First, informal rules that specify the behavior that formal rules ascribe are considered "complementary." In the case of the EU, we can think of various unwritten rules of procedures such as norms about the proper sequence of countries assuming the rotating presidency of the Council of Ministers. Second, informal rules that effectively alter the effects of formal rules without directly violating them are called "accommodating." An example would be the norm to search for a consensus for as long as possible even if a decision is subject to majority voting. Third, there are informal rules "competing" with and, thus, potentially undermining existing formal rules. For example, it is plausible to argue that the European Council's rise in power came at the direct expense of the Commission. It began as an extra-legal forum that, because of the political clout of its members, came to set the EU's political agenda-a task originally reserved for the Commission. Fourth, informal rules that make up for the weakness or absence of formal rules are called "substitutive." In the aforementioned example, some argue that rather than competing with the Commission, the heads of state and government were simply forced to step into a void that a declining Commission had left. ${ }^{1}$ As the last example demonstrates, a behavioral definition of the concept of informal governance cannot remain descriptive. It also has to take into account the reasons behind the emergence of the informal rule in question.

\section{Definitions of informal governance in EU studies and International Relations}

The concepts developed by Helmke and Levitsky are certainly helpful in the context of comparative politics, but they reach their limits when they are applied to the EU. First, lacking a monopoly on violence, it is not clear what the equivalent of enforcement within "officially sanctioned channels" is in the context of the EU. In this vein, Farrell and

\footnotetext{
${ }^{1}$ For an evaluation of these different explanations, see, e.g. Kleine 2013a, chapter 3.
} 
Héritier (2007, 242) define formal rules as rules that are subject to third party enforcement. However, the EU's legal system is an intricate equilibrium that is based on the norms and interests governing the relationship between the European Court of Justice and domestic courts - not the use of force. Some scholars argue that the EU's efforts not to upset this equilibrium itself offers ample opportunities for informal governance (König and Mäder 2013; Carrubba, Gabel, and Hankla 2008). Second, there are large differences among actors at the EU level in the extent to which their behavior depends on "officially sanctioned channels." While EU institutions only exist by virtue of the treaties and can therefore only act within the realm that these treaties define, EU governments can pursue their interests within or outside the EU. In other words, the European Parliament simply would not exist if it were not mentioned in the treaties. This raises the interesting philosophical question whether an institution whose very existence is based on the thirdparty enforcement of existing formal rules can ever really act outside officially sanctioned channels.

The comparative politics concepts of formal and informal rules are even more problematic when applied to the international realm beyond the EU. Much of international law (e.g. conventions) lacks explicit provisions for third-party enforcement (Koremenos 2013, 140). Even if it does, international courts risk remaining toothless if not backed by powerful states or domestic courts. In view of these enforcement problems in international politics, International Relations scholars hold different views about what constitutes an effective formal rule and, by implication, what is to be considered "informal." Building on the concept of legalization in international politics, informal and formal rules are believed to differ from formal ones in terms of their precision (Abbott and Snidal 1998, 10), the obligations they impose (Abbott and Snidal 2000, 454), or the level of delegation they entail (Vabulas and Snidal 2013). Others simply consider as formal a rule that has been put into writing and informal more broadly as unwritten agreements (Lipson 1991, 498).

To avoid an abstract and for our purposes fruitless debate about the state-like character of the EU, I follow Lipson and approach formal rules broadly as rules that have been put into legal writing by official entities. However, I do this from a behavioral perspective in that I consider as rules only those prescriptions that effectively serve as constraints on action (North 1990). Thus, written prescriptions with no actual bearing on behavior do not qualify as rules. On this basis, I consider as informal those unwritten rules that govern regular interactions among two or more actors. They qualify as governance when, according to Keohane and Nye $(2000,12)$, they "guide the collective activities of a group." This means that we should exclude from our definition unilateral practices that are mere acts of non-compliance.

Adapting Helmke and Levitsky's categories slightly, we are left with at least three ways in which formal rules relate to informal ones (Kleine 2014; see also Piattoni 2006, 60). First, it is possible that we observe unwritten agreements where no formal rules exist. Here one can mention various commitments by private companies to adhere to certain norms of social and environmental responsibility (Green 2014). With respect to the EU, the origins of its Common Foreign and Security Policy are rooted in informal chats among the member states' foreign ministers on topics that back then fell outside the remit of the treaties. Second, informal agreements specify existing formal rules that are 
themselves ambiguous or incomplete. For example, the treaties leave much room for the EU institutions to specify their own rules of procedures. In many cases, e.g. practices in the assignments of rapporteurs, these rules often merely formalized what had become established practice before. Third, informal governance may contradict existing formal rules without diminishing their existence, or systematic departures from the formal rules (Stone 2011, 127; Kleine 2013b, 37).

The article elaborates on the third type of informal governance-systematic departures from the formal rules - in more detail further below. For now it suffices to know that it differs from the second type-specifications of existing formal rules-as it seemingly violates the purpose of the formal rule in question. Importantly, this definition is not about mere non-compliance, which is not a form of governance. Non-compliance is a unilateral action that impairs the effectiveness of existing formal rules. Rather, the third type of informal governance describes departures from the formal rules that all actors agree is appropriate in the situation at hand. For example, the EU treaty mandated the European Central Bank to pursue price stability and not to bail out members of the Eurozone. Yet it can be argued that the ECB was forced to violate this mandate in the face of the sovereign debt crisis in order to prevent a collapse of the Eurozone.

\section{The debate about the legitimacy of informal governance}

There is surprisingly little work on the normative implications of these different types of informal governance. In comparative politics, Helmke and Levitsky (Helmke and Levitsky 2004, 728) make a broad distinction between functional informal rules that improve the problem-solving capacity and efficiency of institutions on the one hand, and informal rules that are considered a threat to democratic politics. Unfortunately, they do not discuss whether or not functional informal rules may also impede the democratic character of institutions. Lauth (2000) elaborates on the various ways in which informal institutions may affect the participatory character of democratic political orders. Discussing several institutions outside formal state-sanctioned channels, such as clientelism, corruption, civil disobedience and custom law, he concludes that most of these types harm the participatory quality of democracy and only exert a positive impact if the formal democratic institutions are weak to begin with (Lauth 2000, 44). Despite this nuanced view, Lauth applies a quite narrow normative measure to his discussion that cannot easily be applied beyond the nation state where political orders face clear functional limits to democratic participation.

Some authors look more specifically at the EU and its versions of informal governance. Christiansen, Føllesdal and Piattoni $(2003,1)$ come closest to a definition of informal governance as unwritten agreements where no other formal rules exist. They describe informal governance (somewhat tautologically) as "informal networks that link policy makers to client groups as well as actors across the EU, national and sub-national institutions, and influence (or at least seek to influence) decision-making in the EU.” Their verdict on its legitimacy is largely negative. Although conceding that informal governance might improve the EU's creative problem-solving capacity in the short run, they argue that without mechanisms of transparency, accountability and authority it remains doubtful that it remains effective in the long run (Christiansen, Føllesdal, and 
Piattoni 2003, 13). Reh adopts a similar definition, describing informal politics as practices that exclude some entitled actors, typically take place in secluded settings, and produce decisions that are not officially binding. Like Christiansen and colleagues, she finds that while informal politics might increase the efficiency of decision-making, it comes at the price of reduced deliberation and accountability (Reh 2012, 80; 2014; similarly, Lord 2013).

Farrell and Héritier come closer to the second type of informal governance as uncodified specifications of existing yet incomplete formal rules (Farrell and Héritier 2007, 228). It is worth noting that this definition is initially value-free as it does not in itself presume informal governance to have specific effects on existing formal decision-making procedures. However, discussing the case of early agreements that regularly conclude negotiations between the Council and the European Parliament without exhausting all stages of the legislative procedure, Farrell and Héritier argue that this specific form of informal politics, while enhancing the efficiency of decision-making, carries a price for legitimacy by privileging the participation of larger parties, obscuring the decisionmaking process, and reducing opportunities for national parliaments to hold their governments to account (Farrell and Héritier 2003, 7-8). Overall, Farrell and Héritier are less critical than Christiansen and colleagues, Reh or Lord about the impact of informal governance on the EU's legitimacy. This is arguably because they do not consider informal governance to be inherent in EU politics. They regard it as an interstitial practice that actors will formalize once they become established (Farrell and Héritier 2007, 240).

There is a growing literature in International Relations that deals with the third type of informal governance as systematic departures from formal rules. Recall that these departures are not mere non-compliance, but are considered appropriate in the situation at hand even if they violate the formal rule's purpose. This literature is the least specific about the normative implications of informal governance and focuses mainly on its potential upsides. Both Stone and Kleine consider situations in which systematic departures from the formal rules allow states to retain a high level of cooperation by occasionally giving more weight to those interests that are able to disrupt it (Stone 2011, 33; Kleine 2013b, 163-165). However, the literature remains silent about the potential downside of this form of informal governance. The following section takes a closer look at this question.

\section{Informal governance, formal rules departures, and legitimacy}

Scholars arrive at different conclusions regarding the legitimacy of informal governance, depending on its definition and reasons behind the practice in question. For the purpose of space and because it has so far received less attention, the remainder of this article zooms in on the last type of informal governance as systematic departures from formal rules in order to evaluate how it affects the legitimacy of the EU's political order. We remarked earlier that a behavioral definition of informal governance cannot remain descriptive and also has to take into account the various reasons behind the emergence of these systematic practices. 


\section{Roots of Informal Governance}

There are at least three general explanations for why governments and other actors systematically depart from formal rules: power, political uncertainty, and political exchange. Stone (2011) views informal governance as the result of an attempt to accommodate powerful member states. The logic is the following: Because powerful states have opportunities to act unilaterally to pursue urgent strategic interests, small states offer them a deal in order to keep them on board. In exchange for more favorable formal voting rights in normal times, they permit the powerful state to assume informal control of the organization whenever it considers its important interests to be at stake.

Whether or not a state is tempted to pursue its interest outside of an international organization is typically a matter of domestic politics, the dynamics of which can in turn be manipulated by the international organization itself. In my own work (Kleine 2013a), I have argued that states collectively depart from formal rules in order to accommodate governments that are under unexpectedly strong domestic pressure to defy an international organization. Assuming that the domestic consequences of international cooperation are not always predictable, domestic groups that are suddenly confronted with unexpected concentrated adjustment costs may suddenly mobilize against an international agreement and pressure its government into delaying, obstructing, or even openly defying it. This "political uncertainty" threatens to damage states' expectations about one another's commitment, the very backbone of their cooperation. To keep the basis of their cooperation intact, states collectively depart from the formal procedures to accommodate governments under exceedingly strong domestic pressure, and they concede just enough to restore such governments' incentive to cooperate.

A final set of studies emphasizes the fact that states may choose not to enforce formal rules against one another when they expect to receive the same favor on important matters. This insight about the gains from political exchange of formal rights and obligations form the basis of Christina Scheider's (2013) study on budget negotiations in the European Union, in which she discovers that governments reciprocally funnel monetary transfers to one another in order to help governments facing domestic elections appear more competent in the eyes of voters. Political exchange has also been cited as a reason for the allocation of certain portfolios within the Commission. Despite the fact that the Commission is supposed to be independent, states tolerate the fact that certain divisions informally "belong" to certain (groups of) member states. These "national fiefdoms," I argue, are the result of an exchange of informal control over the governments' most preferred divisions within an international bureaucracy (Kleine 2013d).

\section{Informal governance and legitimacy}

How legitimate are these three reasons behind systematic departures from the formal rules? From a sociological perspective, we can consider a social or political order legitimate if the members consider its rules both appropriate and binding (Weber 1980). As an empirical concept, the legitimacy of a political order may have various, not 
mutually exclusive roots. For our purpose, it is important to note that a political order may generate and reinforce existing beliefs about its own legitimacy in more than one way. In that context, Fritz Scharpf and other scholars distinguish between input, throughput and output legitimation mechanisms, with input referring to the participatory quality, throughput to the procedural quality, and output to the problem-solving quality of a political order (Scharpf 1999; Zürn 1998, 2000; Risse and Kleine 2007).

\section{Informal governance and input legitimacy}

Input legitimacy refers to a process where the possibility of participating in the making of a rule and having one's voice considered strengthens the belief in the appropriateness and bindingness of the resulting rule, independently of whether or not it reflects one's interests. Inclusive participation is typically equated with the democratic process, in which all citizens that are affected by a decision are either directly or indirectly represented in its making. From this perspective, the process of globalization poses a formidable challenge to the legitimacy of national political orders. Globalization creates a state of complex interdependence where the effects of a decision taken in one country can be felt well beyond its borders (Keohane and Nye 1977).

Even if the congruence between those who govern and those that are governed is restored through international cooperation, critics argue that the quality of participation and, thus, the legitimacy of a political order nevertheless suffers as authority is delegated from the national to the international level. For example, Dahl $(1994,28)$ contends that the delegation of authority to a higher level necessarily limits both citizens' capacity and opportunity to engage in democratic processes. Føllesdal and Hix $(2006,15)$ problematize the fact that policies at the international level tend to be less responsive to changes in the preferences of citizens, since the making of decisions at the international level is often delegated to non-majoritarian institutions or is cumbersome for other reasons.

Let us assume for the moment that the skeptics are right and that the delegation of authority to the international level limits participation and, therefore, puts the legitimacy of political orders at jeopardy. ${ }^{2}$ How does informal governance play into this problem? The short answer is that this depends on the type of informal governance we are dealing with. Recall that the power-based perspective claims that informal governance is the result of large states assuming control of an international organization when they consider their important interests to be at stake. If this is indeed the case, then citizens of a large state gain influence compared to citizens in smaller states simply due to the fact that they cluster in a certain geographical area, and not because they are more severely affected than others. To see this, consider a situation where all small states have similar strong interests as the large state. They may jointly even represent a larger number of citizens than the large state. Yet, according to Stone's model, it is the large state that overrides the institution due to the fact that its outside options are more credible than those of the small

\footnotetext{
${ }^{2}$ It should be noted that this causal link between participation and legitimacy is stipulated, but rarely tested. Skeptics argue that the policies international organizations deal with do not lend themselves to political debate (Moravcsik 2008, 338-339).
} 
states. ${ }^{3}$ As a result, the legitimacy of the political order in the eyes of the small states decreases.

The assessment is different when we consider informal governance as the result of political uncertainty. States use this form of governance in order to accommodate groups facing unexpectedly concentrated adjustment costs that incentivize this group to mobilize and pressure their government into defection (Kleine 2013b). Informal governance as a result of political uncertainty therefore includes those in the political process that are more strongly affected than legislative actors had estimated. In comparison to a situation in which these interests are disregarded in the initial decision, this form of informal governance would improve the legitimacy of the political order as it shows citizens that legitimate interests are being considered.

Let us finally consider how informal governance as the result of political exchange impacts on the input legitimacy of a political order. In this version, the political arena acts as a kind of market place in which legislative actors trade rights and responsibilities. Informal governance ensues when actors relinquish some rights and responsibilities on issues they care less about in exchange for more influence on issues about which they care more. In my own work on national fiefdoms, for example, I discuss how countries that care a lot about one but not another policy trade their rights and responsibility so that countries that care a lot about a certain sector ability (e.g. France on agriculture) are better able to control the work of an international bureaucracy in this field (Kleine 2013d). A deal like this in principle improves input legitimacy by giving those countries more control over decisions that disproportionately affect them.

If informal governance is based on market logic, does it mean that states with greater (market) power have more input in the decision-making process? We should note that we are here dealing with a different type of power from before, namely one that is exercised in a context of complex interdependence in which influence depends at least as much on the intensity of one's preference as on size (for a discussion see, e.g., Keohane and Nye 1977). While in the previous type of informal governance power enables states to pursue their intense interests, the exchange logic implies that intense preferences may even diminish power, since they make states in pursuit of their interests dependent on the cooperation of others. ${ }^{4}$ Thus, as long as the trade is voluntary, informal governance as a result of political exchanges improves input legitimacy as it grants actors that are more strongly affected by an issue greater influence on that matter, compared with a counterfactual situation of equal voice.

However, all these versions of informal governance are prone to manipulation and abuse. A large power might be tempted to assume control of an international organization more often than the small states deem it necessary. Domestic groups that know that they will be accommodated if they complain loudly enough have incentives to mobilize regardless of whether or not they are disproportionately hit by international cooperation. If legislative actors are merely trading their rights and responsibilities for personal gain, then we are

\footnotetext{
${ }^{3}$ Of course, small states could try to cooperate and jointly threaten to leave the organization. However, an alliance like this is difficult to form and sustain, which renders the outside options of the large state more credible.

${ }^{4}$ Both types of power are not conceptually different. Power is much more dictated by preference asymmetries than sheer size when it exercised in a context of complex interdependence.
} 
dealing with a case of rent seeking, if not corruption (see, e.g., Schneider 2013). The EU is walking a tightrope when it decides to depart from the rules in order to give special consideration to intense preferences. To prevent these decisions from undermining the credibility and value of the political order they are meant to sustain, EU actors require additional mechanisms that allow them to distinguish between legitimate and nonlegitimate for accommodation. As I have argued elsewhere, this is why informal governance is often accompanied by some form of adjudicatory mechanism that elicits information about the preference formation process (Kleine 2013c). ${ }^{5}$ Only if all governments agree on its need can informal governance be considered a more legitimate form of governance than its formal counterpart.

Informal governance and throughput legitimacy

Another aspect of legitimacy concerns the quality of the decision-making process itself, throughput legitimacy (Schmidt 2013; Risse and Kleine 2007). In other words, it is the process of decision-making itself that strengthens the belief in the appropriateness and bindingness of the resulting rule, independently of whether or not it reflects one's interests.

A first component of throughput legitimacy in systems of representative democracy is accountability, which, according to Ruth Grant and Robert Keohane, "implies that some actors have the right to hold other actors to a set of standards, to judge whether they have fulfilled their responsibilities in light of these standards and to impose sanctions if they determine that these responsibilities have not been met” (Grant and Keohane 2005, 29). A prerequisite of accountability in parliamentary democracies is transparency (Strøm 2000): it allows citizens to gather information about their representatives' behavior and, consequently, to punish a digression from their mandate (Fearon 1999; similarly, for the EU context, Curtin 2007, 532). In that respect, all types of informal governance have the potential to weaken the throughput legitimacy of a political order compared to a situation where formal rules are followed by the letter. ${ }^{6}$ If citizens have a stake in a decision, but are unable to follow who took it on what grounds, they are also unable to punish a politician for not representing their interests. Informal governance consequently creates incentives for politicians to abuse their increased room of maneuver for personal gains. However, governments may devise alternative accountability mechanisms to ensure that, at a minimum, informal governance does not harm the collective interest. As mentioned earlier, an informal norm in the EU says that member states with a special interest in a certain policy area be granted special control over the respective department in the Commission. At the same time, another informal norm requires that state to ensure a minimum of national diversity in this department, in order to prevent conflicts with other states’ interests (Kleine 2013d, 2015).

A second component of throughput legitimacy concerns the quality of the decision-

\footnotetext{
${ }^{5}$ Note that an information-rich environment is not the same as transparency, which refers to the availability of information to the public.

${ }^{6}$ It should be noted that the causal link between transparency and legitimacy is an empirical question. Citizens do not always follow political processes even if information about it is readily available. See, e.g., De Fine Licht, Naurin, Esaiasson and Gilljam 2014, .
} 
making process. Proponents of deliberative democracy (Cohen and Sabel 1997; Elster 1998b; Habermas 1992) suggest that processes that systematically allow for arguing, reason-giving and mutual learning rather than hard-nosed bargaining will have a substantially improved chance of leading to better outcomes. The main reason is that arguing and reason giving provide a mechanism to probe and challenge the normative validity of actors' interests as well as to check the empirical facts on which policy choices are based (similarly, for the EU context, Stie 2013, 44-45). There is some disagreement to what extent the transparency of a process is a prerequisite for deliberation to prevail. According to Elster (1998a, 104), discussions in a public sphere ensure that actors have to explain and justify their behavior in line with constraints such as the consistency of a line of reasoning and the plausibility of claims. In other words, powerful social norms held by the audience force actors to behave in ways that are not perceived as selfish. From this perspective, all types of informal governance would make it more difficult for an audience to play this disciplining role, because arguments that are not consistent with previous (public) statements can more easily be made behind the scenes.

Other scholars, however, disagree with the disciplining role of the public audience. In their view, audiences are composed of different groups with different interests that they want their government to pursue in a discussion. Given that negotiations require some give and take between the negotiating actors, the fact that these domestic groups follow the talks closely narrows the negotiator's room for maneuver (Stasavage 2004) and, therefore, the possibility of letting oneself be persuaded (Pettit 2004). In this light, informal governance has a very different effect on the deliberative quality of decisionmaking. As discussed before, the departure from formal rules makes it more difficult for the public to assess in real time which decision has been taken by whom on what grounds. This additional room for maneuver may also give politicians the space to allow themselves to be persuaded by a better argument in an environment where they would otherwise be forced to pursue myopic and socially inculcated interests (Buchanan 2004, 128; similarly, Keohane, Macedo, and Moravcsik 2009, 8). In other words, informal governance may improve the epistemic quality and, thereby, the legitimacy of a decision provided that it is possible to hold the decision maker accountable for her change of heart.

\section{Informal governance and output legitimacy}

The last way in which a political order may constantly regenerate its own support is by delivering results. In other words, citizens are believed to support a political order when it improves their situation, independent of whether or not they have been included in the decision or approve of the way it was taken. Some scholars even argue that since it is more difficult for international orders to generate legitimacy in other ways, they should focus primarily on strengthening their output legitimacy (Scharpf 1999, 189; Majone 2005).

How does informal governance affect the output legitimacy of an international political order? Considering power-based informal governance, it can be said to strengthen the output legitimacy of an international organization since, compared with a counterfactual 
situation, there would be no cooperation with the participation of large states to begin with. In Stone's view, informal governance allows large states to commit credibly to cooperation even in situations where the institution's formal rules no longer suit their interests. Small states, on the other hand, are able to keep larger states on board and, thus, profit from a larger capacity. All states are consequently better off.

The same holds true for informal governance as a result of political uncertainty. In this theory, the members of an international organization accommodate a government to prevent it from caving in to unexpectedly high domestic pressure. The reason is neither reciprocity nor power. It is the common understanding that any unilateral departure from the formal rules destroys what underpins their cooperation, namely stable expectations about one's rule-following behavior. Informal governance with a view to accommodating governments under pressure and restoring the credibility of their commitment consequently upholds a level of cooperation that they would otherwise not be able to sustain. It, too, improves output legitimacy.

The result is more mixed when we look at political exchanges. The counterfactual situation without this type of informal governance implies a different distributional outcome, not the demise of the political order per se. Although an outcome based on voluntary exchanges is, in the strictest sense of the word, Pareto-improving (nobody is worse off and at least one actor is better off), this does not mean that it serves the public interest. Consider Schneider's work on how governments depart from objective budget allocation criteria in order to help each other look more competent in the eyes of the voter. In this case, it is the politicians that are personally better off, but not the national publics or the general European public at large. However, the public interest and, therefore, output legitimacy are elusive concepts that can neither be derived from normative ideals nor from potentially intransitive collective interests. But if the public interest cannot be derived from the ideal or the concrete, it must result from a process that, at the very minimum, prevents the abuse of informal governance for personal gains (Steffek 2015, 272-274). In short, informal governance as the result of political exchanges is unlikely to improve the legitimacy of a political order unless it is accompanied by throughput mechanisms that ascertain whether or not the final outcome is indeed, from the public's point of you, preferable to the counterfactual outcome under the formal rules.

\section{Conclusion}

In public as well as scholarly debates, informal governance holds an aura of the covert, exclusive, even illegitimate that goes against the democratic ideal of an open and inclusive process. All too often, however, existing analyses conflate different types of informal governance or consider predominantly its effect on transparency and accountability. To offer a more nuanced assessment of this relationship, I identified various definitions of informal governance. I then distinguished between three channels of legitimation - input, throughput, and output - through which a political order can regenerate the support that is necessary to sustain it and, against this background, discussed how a specific form of informal governance as a response to asymmetries in 
power, political uncertainty and political exchange may affect the way that citizens perceive rules as appropriate and binding.

This paper argued that the relationship between informal governance and legitimacy is much more complex and to some extent counter-intuitive. In terms of input-legitimacy, the paper argued that not all forms of informal governance are exclusive, but emerge precisely in order to include the intense interests of actors that would otherwise have been ignored. Considering throughput, the paper found that while the elusiveness of informal governance opens the door for manipulation and abuse, it also affords politicians the flexibility to let themselves be persuaded by better arguments. Finally, informal governance as the result of power and political uncertainty may improve the output legitimacy of informal governance by allowing states to achieve a level of cooperation that would otherwise be unsustainable. In short, the impact of informal governance on the legitimacy of an international political order is an empirical question and ultimately depends on the extent to which it relies on the one or the other path to legitimation.

However, informal governance is prone to manipulation and abuse, in which case any effect on the legitimacy of the political order is bound to be negative. Large states that stretch their unilateral influence on the political order beyond what small states are willing to tolerate, domestic groups that exaggerate the adjustment costs that they are facing, and politicians that engage in political exchanges solely for personal gain neither serve to include those that are most affected by a decision, nor do they help attain the greater public good. Any positive effect that informal governance may have on the legitimacy of the political order therefore depends on whether additional mechanisms can elicit information that help all governments distinguish between legitimate and nonlegitimate demands for a more accommodating treatment of each other.

Given that the relationship between informal governance and legitimacy is complex, we should be more careful about calls to get rid of informality and improve the transparency of political processes. Our analysis suggests that, at best, those efforts will be fruitless when they merely deal with a symptom without changing the structures that create incentives for the use of informal governance. In that case, actors will find other and likely even more covert ways around the formal rules. If, for example, informal governance is an outgrowth of power asymmetries, it is naïve to think that institutional reforms could prevent a large state from assuming more control of an international organization when its very intense preferences are at stake. Even worse, however, reforms aimed at ridding an international organization of informal governance risk aggravating the situation when they destroy exactly those aspects that help improve the organization's legitimacy.

Our finding that informal governance may under certain circumstances have a positive impact on the legitimacy of a political order is likely to run counter to our normative intuitions. In fact, one might argue that any empirical effect on legitimacy is ephemeral unless the political order is based on a moral justification of the exercise of power (Lord 2013, 1058; Buchanan 2002, 689). Thus, informal governance may regenerate governments' support of the political order. But is this support sustainable unless it trickles down to a wider population, underpinned by a broad consensus that the order is appropriate and binding? 
One might further object that by systematically departing from the formal rules, even in expectation of a tangible or intangible benefit, decision makers relinquish their formal rights and, thus, neglect a civic duty. From this perspective, there is a moral value in the membership of a political order beyond mere material benefit. To exercise the formal rights and obligations of this political order through practice is to cultivate and strengthen its bonds (Sandel 1998, 108). Systematic departures from formal rights and obligations would therefore corrupt the value of membership in the political order and ultimately lead to its demise.

Both normative objections go to the very heart of the debate about the nature of the European Union. As to the first objection, it is debatable whether a moral justification is primarily required for political orders that are backed up by a monopoly of force rather than by voluntary association (Nagel 2005, 115, 140), and whether the EU or other international political orders can ever hope to acquire this characteristic. At the very least, certain forms of informal governance can be said to avert the erosion of a given level of legitimacy precisely when a broad moral justification of the political order is wanting, namely by preventing situations in which intense interests, be they the interests of domestic groups or large states, are disregarded. Regarding the second objection, we should note that informal governance is not the same as non-compliance. Systematic departures from formal rules can become part of the fabric of a political order, and its exercise in cases that are considered legitimate by all governments may just as much cultivate bonds, even if only among the governments. Moreover, it is again questionable to what extent the EU goes beyond a transactional union that bestows civic duties on its members - a debate that is echoed in discussions about opt outs and a future association with the United Kingdom after a possible Brexit. These debates are likely to continue but, unfortunately, go beyond the scope of this paper. 


\section{References}

Abbott, Kenneth W., and Duncan Snidal. 1998. "Why States Act through Formal International Organizations." Journal of Conflict Resolution no. 42 (1):3-32. doi: $10.1177 / 0022002798042001001$.

-. 2000. "Hard and Soft Law in International Governance." International Organization no. 54 (3):421-456.

Buchanan, Allen. 2002. "Political Legitimacy and Democracy." Ethics no. 112 (4):689719. doi: $10.1086 / 340313$.

_. 2004. "Political Liberalism and Social Epistemology." Philosophy \& Public Affairs no. 32 (2):95-130.

Carrubba, Clifford J., Matthew Gabel, and Charles Hankla. 2008. "Judicial Behavior under Political Constraints: Evidence from the European Court of Justice." American Political Science Review no. 102 (4):435-452.

Christiansen, Thomas, Andreas Føllesdal, and Simona Piattoni. 2003. "Informal governance in the European Union: an introduction." In Informal governance in the European Union, edited by Thomas Christiansen and Simona Piattoni, 1-21. Cheltenham, UK: Edward Elger Publishing.

Cohen, Joshua, and Charles Sabel. 1997. "Directly-Deliberative Polyarchy." European Law Journal no. 3 (4):313-342.

Curtin, Deirdre. 2007. "Holding (Quasi-)Autonomous EU Administrative Actors to Public Account." European Law Journal no. 13 (4):523-541. doi: 10.1111/j.14680386.2007.00382.x.

Dahl, Robert A. 1994. "A Democratic Dilemma. System Effectiveness versus Citizen Participation." Political Science Quarterly no. 109 (1):23-34.

Elster, Jon. 1998a. "Deliberation and Constitution Making." In Deliberative Democracy, edited by Jon Elster, 97-122. Cambridge, Mass.: Cambridge University Press. . 1998b. Deliberative Democracy. Cambridge: Cambridge UP.

Farrell, Henry, and Adrienne Héritier. 2003. "The Invisible Transformation of Codecision: Problems of Democratic Legitimacy." Sieps Report no. 7.

- 2007. "Introduction: Contested Competences in the European Union." West European Politics no. 30 (2):227-243.

Fearon, James D. 1999. "Electoral Accountability and the Control of Politicians: Selecting Good Types versus Sanctioning Poor Performance." In Democracy, Accountability, and Representation, edited by Adam Przeworski, Susan C. Stokes and Bernard Manin, 55-97. Cambridge, UK: Cambridge University Press.

Føllesdal, Andreas, and Simon Hix. 2006. "Why There is a Democratic Deficit in the EU: A Response to Majone and Moravcsik." Journal of Common Market Studies no. 44 (3):533-562.

Grant, Ruth W., and Robert O. Keohane. 2005. "Accountability and Abuses of Power in World Politics." American Political Science Review no. 99 (1):1-15.

Green, Jessica F. 2014. Rethinking Private Authority. Agents and Entrepreneurs in Global Environmental Governance. Princeton: Princeton University Press.

Habermas, Jürgen. 1992. Faktizität und Geltung. Beiträge zur Diskurstheorie des Rechts und des demokratischen Rechtsstaats. Frankfurt/M.: Suhrkamp. 
Helmke, Gretchen, and Steven Levitsky. 2004. "Informal Institutions and Comparative Politics: A Research Agenda." Perspectives on Politics no. 2 (04):725-740. doi: doi:10.1017/S1537592704040472.

Keohane, Robert O., Stephen Macedo, and Andrew Moravcsik. 2009. "DemocracyEnhancing Multilateralism." International Organization no. 63 (01):1-31. doi: doi:10.1017/S0020818309090018.

Keohane, Robert O., and Joseph Nye. 1977. Power and Interdependence. World Politics in Transition. Boston, MA: Little, Brown and Co.

Keohane, Robert O., and Joseph S. Nye. 2000. "Introduction." In Governance in a globalizing world, edited by John D. Donahue and Joseph S. Nye, 1-41. Washington D.C.: Brookings Institution.

Kleine, Mareike. 2013a. "Informal Governance in the European Union." Journal of European Public Policy no. 21 (2):303-314. doi: 10.1080/13501763.2013.870023. . 2013b. Informal Governance in the European Union. How Governments Make International Organizations Work. Ithaca, NY: Cornell University Press.

—. 2013c. "Knowing your limits: Informal governance and judgment in the EU." The Review of International Organizations no. 8 (2):245-264. doi: 10.1007/s11558-012-9148-7.

. 2013d. "Trading control: national fiefdoms in international organizations." International Theory no. 5 (3):321-346.

- 2014. "Informal governance in the European Union." Journal of European Public Policy no. 21 (2):303-314.

- 2015. Keeping tabs on your cooperating partners: a coalition government perspective on international bureaucracies. Paper presented at the 2015 APSA annual meeting in San Francisco.

König, Thomas, and Lars Mäder. 2013. "The Strategic Nature of Compliance: An Empirical Evaluation of Law Implementation in the Central Monitoring System of the European Union." American Journal of Political Science. doi: 10.1111/ajps.12038.

Koremenos, Barbara. 2013. "What's left out and why? Informal provisions in formal international law." The Review of International Organizations no. 8 (2):137-162. doi: 10.1007/s11558-012-9159-4.

Lauth, Hans - Joachim. 2000. "Informal institutions and democracy." Democratization no. 7 (4):21-50.

Lipson, Charles. 1991. "Why Are Some International Agreements Informal?" International Organization no. 45 (4):495-538.

Lord, Christopher. 2013. "The democratic legitimacy of codecision." Journal of European Public Policy no. 20 (7):1056-1073.

Majone, Giandomenico. 2005. Dilemmas of European integration. The ambiguities and pitfalls of integration by stealth. Oxford: Oxford University Press.

Nagel, Thomas. 2005. "The Problem of Global Justice." Philosophy and Public Affairs no. 33 (2):113-147.

North, Douglass. 1990. Institutions, Institutional Change and Economic Performance. Cambridge: Cambridge University Press.

Pettit, Philip. 2004. "Depoliticizing Democracy." Ratio Juris no. 17 (1):52-65. 
Piattoni, S. 2006. "Informal governance in structural policy." Perspectives on European Politics and Society no. 7 (1):56.

Reh, Christine. 2012. "Informal politics: the normative challenge." In International Handbook of Informal Governance, edited by Thomas Christiansen and Christine Neuhold. London: Edward Elgar.

— 2014. "Is informal politics undemocratic? Trilogues, early agreements and the selection model of representation." Journal of European Public Policy no. 21 (6):822-841.

Risse, Thomas, and Mareike Kleine. 2007. "Assessing the Legitimacy of European Treaty Revisions." Journal of Common Market Studies no. 45 (1):60-80.

Sandel, Michael J. 1998. What Money Can’t Buy: The Moral Limits of Markets. The Tanner Lectures on Human Values. Delivered at Brasenose College, Oxford. May 11 and 12, 1998.

Scharpf, Fritz W. 1999. Governing in Europe. Effective and Democratic? Oxford, UK: Oxford University Press.

Schmidt, Vivien A. 2013. "Democracy and legitimacy in the European Union revisited: input, output and 'throughput'." Political Studies no. 61 (1):2-22.

Schneider, Christina J. 2013. "Globalizing Electoral Politics: Political Competence and Distributional Bargaining in the European Union." World Politics no. 65 (03):452-490. doi: doi:10.1017/S0043887113000129.

Stasavage, David. 2004. "Open-Door or Closed-Door? Transparency in Domestic and International Bargaining." International Organization no. 58 (4):667-703.

Steffek, Jens. 2015. "The output legitimacy of international organizations and the global public interest." International Theory no. 7 (2):263-293.

Stie, Anne Elisabeth. 2013. Democratic Decision-making in the EU. Technocracy in disguise? London and New York: Routledge.

Stone, Randall W. 2011. Controlling Institutions. International Organizations and the Global Economy. Cambridge, UK: Cambridge University Press.

Strøm, Kaare. 2000. "Delegation and accountability in parliamentary democracies." European Journal of Political Research no. 37 (2):261-289.

Vabulas, Felicity, and Duncan Snidal. 2013. "Organization without delegation: Informal intergovernmental organizations (IIGOs) and the spectrum of intergovernmental arrangements." The Review of International Organizations no. 8 (2):193-220. doi: 10.1007/s11558-012-9161-x.

Weber, Max. 1980. Wirtschaft und Gesellschaft. Tübingen: J.C.B. Mohr.

Zürn, Michael. 1998. Regieren jenseits des Nationalstaats. Globalisierung und Denationalisierung als Chance. Frankfurt/ Main: Suhrkamp.

. 2000. "Democratic Governance Beyond the Nation-State: The EU and Other International Institutions." European Journal of International Relations no. 6 (2):183-221. 